Mariusz Zajączkowski

Instytut Studiów Politycznych Polskiej Akademii Nauk w Warszawie Instytut Pamięci Narodowej w Lublinie

\title{
Wierzchowiny i NSZ. Uwagi krytyczne na marginesie książki Mariusza Bechty i Wojciecha J. Muszyńskiego Przeciwko Pax Sovietica. Narodowe Zjednoczenie Wojskowe i struktury polityczne ruchu narodowego wobec reżimu komunistycznego 1944-1956
}

Od przełomu ustrojowego 1989 r. w polskiej historiografii z różnym natężeniem toczy się spór dotyczący podłoża i skali zbrodni popełnionych na obywatelach Rzeczypospolitej przez polskie podziemie antykomunistyczne we wczesnych latach powojennych. Od kilku lat przybiera on postać szczególnie żarliwych polemik. Zagadnienie czarnych kart „żołnierzy wyklętych” wywołuje też nie mniej ożywione dyskusje publicystyczne ${ }^{1}$. Obecne jest także w przestrzeni wirtualnej ${ }^{2}$. Negatywne emocje zwiazane z ta kwestia budzą również inicjatywy ustawodawcze podejmowane przez niektóre środowiska polityczne w polskim parlamencie na gruncie tzw. polityki historycznej. Świadczą o tym liczne kontrowersje wokół nowelizacji ustawy o Instytucie Pamięci Narodowej (IPN), która weszła w życie 1 III 2018 r. W spór ten bez wątpienia wpisuje się monografia Mariusza Bechty i Wojciecha J. Muszyńskiego, Przeciwko Pax Sovietica. Narodowe Zjednoczenie Wojskowe $i$ struktury polityczne ruchu narodowego wobec reżimu komunistycznego 1944-1956, która ukazała się jesienia 2017 r. nakładem Wydawnictwa IPN. Książka ta była długo wyczekiwana

\footnotetext{
${ }^{1}$ P. Zychowicz, Skazy na pancerzach. Czarne karty epopei Żotnierzy Wyklętych, Poznań 2018.

${ }^{2}$ Zob. np.: https://zolnierzeprzekleci.wordpress.com/ (dostęp: 17 II 2018).
} 
przez środowiska hołdujące tradycji narodowego i nacjonalistycznego nurtu polskiego podziemia antykomunistycznego. W zamierzeniu Autorów publikacja miała bowiem m.in. rzucać „nowe światło na okoliczności wykreowania przez reżim komunistyczny "czarnej legendy» partyzantki narodowej mordującej współobywateli, której emanacją był tzw. mord w ukraińskich Wierzchowinach 6 VI 1945 r.”3, gdzie życie straciło blisko 200 ukraińskich chłopów (wyznania prawosławnego i świadków Jehowy).

Zdaniem Bechty i Muszyńskiego popełnienie zbrodni w Wierzchowinach niesłusznie przypisuje się wyłącznie lubelskiemu zgrupowaniu oddziałów Akcji Specjalnej (AS)/ Pogotowia Akcji Specjalnej (PAS) Narodowych Sił Zbrojnych (NSZ) pod dowództwem Mieczysława Pazderskiego „Szarego”, gdyż jej współsprawców/ aktorów wydarzeń było więcej. Według prezentowanej przez Autorów teorii 6 VI 1945 r. na podstawie listy proskrypcyjnej partyzanci NSZ rozstrzelali we wsi kilkunastu mieszkańców (zdeklarowanych komunistów). Znacznie więcej ukraińskich ofiar (spoza listy) - choć Bechta i Muszyński zdaja się nie wiedzieć, ile dokładnie - zamordowano jeszcze w trakcie pacyfikacji wsi (przeprowadzanej przez zgrupowanie NSZ samodzielnie lub - jak sugerują - wspólnie z partyzantką poakowska), a następnie po jej zakończeniu i opuszczeniu Wierzchowin przez partyzantów NSZ. Zdaniem Autorów ukraińscy mieszkańcy wsi stracili wówczas życie od ciosów zadanych narzędziami gospodarskimi przez chłopów z okolicznych polskich miejscowości, którzy wyrównywali w ten sposób swoje zadawnione krzywdy ${ }^{4}$. Do ich śmierci mieli przyczynić się też żołnierze Wojska Polskiego (WP), Wojsk Pogranicznych Ludowego Komisariatu Spraw Wewnętrznych (NKWD) ZSRS, funkcjonariusze Milicji Obywatelskiej (MO), w końcu członkowie grupy prowokacyjnej Urzędu Bezpieczeństwa (UB), którzy na wieść o napadzie „reakcyjnego podziemia” $\mathrm{w}$ różnym czasie przybywali do Wierzchowin, rzekomo w celu dokończenia dzieła zniszczenia i tym samym zdyskredytowania „polskich faszystów”. W związku z powyższym książka Przeciwko Pax Sovietica... doczekała się głosów polemicznych ${ }^{5}$.

W niniejszym artykule recenzyjnym odnoszę się do powyższej tezy Autorów, dowodząc, że nie znajduje ona potwierdzenia w zachowanym materiale

\footnotetext{
${ }^{3}$ M. Bechta, W.J. Muszyński, Przeciwko Pax Sovietica. Narodowe Zjednoczenie Wojskowe $i$ struktury polityczne ruchu narodowego wobec rezimu komunistycznego 1944-1956, Warszawa 2017, s. 12.

${ }^{4}$ Autorzy Przeciwko Pax Sovietica... nie precyzuja, czy okoliczni polscy chłopi byli członkami siatki terenowej NSZ plądrującymi zabudowania w Wierzchowinach i mordującymi ich właścicieli pod osłoną zgrupowania „Szarego”, czy też niepowiązanymi z organizacja mieszkańcami sąsiednich polskich wsi, których przywiodła do Wierzchowin okazja zdobycia łatwego łupu po spacyfikowaniu i opuszczeniu tej miejscowości przez partyzantkę eneszetowska.

${ }^{5}$ G. Motyka, Prawda niepetna, „Polityka” 2017, nr 43 (3133); A. Karbowiak, Ksiażka „Przeciwko Pax Sovietica” / Spór o masakrę w Wierzchowinach. Mord obciaża NSZ, „Historia Do Rzeczy” 2017, nr 12 (58).
} 
źródłowym, także proweniencji eneszetowskiej, a zabiegi czynione przez nich w pracy maja wyłacznie na celu wykreowanie i utrwalenie spiżowego obrazu działalności NSZ.

\section{Dziwna metodologia badań historycznych}

Chcąc przystapić do krytycznej analizy przytoczonej na wstępie tezy, natrafiamy na istotny problem. Jest nim ciagła modyfikacja teorii, której od czasu ukazania się książki dokonuje głównie Mariusz Bechta, próbując rysować co rusz to nowe, niekończące się alternatywne wersje wydarzeń z 6 VI 1945 r. ${ }^{6}$ W związku z tym nie do końca wiadomo, która z prezentowanych wersji wydarzeń w Wierzchowinach jest według Bechty i Muszyńskiego właściwa.

Należy podkreślić, że wszystkie warianty charakteryzuje określona cecha wspólna - silna tendencja do rozmywania ostrości obrazu wydarzeń przez wprowadzenie do narracji wielu nieważnych szczegółów. Odnosi się wrażenie, że cały ten nieistotny szum stworzony został tylko po to, aby czytelnikowi niemającemu dostępu do źródeł uniemożliwić lub co najmniej utrudnić dotarcie do sedna problemu. Przejawia się to również w skłonności Autorów do konstruowania hipotez i nieuprawnionych interpretacji bazujacych na mało istotnych źródłach (np. opiniach zasłyszanych po upływie wielu lat od opisywanych wydarzeń, w tym świadectwach osób niebędących uczestnikami akcji na Wierzchowiny). Stosuja oni wreszcie uproszczenia, przemilczenia czy wprost manipulują faktami i dokumentami. Zdarza się, że w jednym miejscu książki przytaczają dokumenty NSZ z 1945 r., by w innym zaprzeczyć ich treści wnioskami wyciagniętymi na podstawie całkowicie pobocznego materiału źródłowego ${ }^{7}$. Niekiedy z informacjami zamieszczonymi na danej stronie książki w tekście głównym kolidują dodatkowe wyjaśnienia zawarte w przypisach poniżej ${ }^{8}$.

Metodologię przyjętą w książce Przeciwko Pax Sovietica... można w zasadzie sprowadzić do stwierdzenia, że jeżeli fakty nie pasują do spiżowego wyobrażenia Autorów o działalności NSZ, to tym gorzej dla faktów. Przejawia się to na przykład w traktowaniu dokumentów NSZ, które stawiaja organizację w złym świetle, a priori jako poprawionych przez komunistów. Dotyczy to zarówno odpisów z odręcznych meldunków i raportów poszczególnych dowódców oddziałów AS/PAS przejętych w 1945 r. przez UB lub NKWD i następnie sporządzonych za zgodność z oryginałem w formie maszynopisów

\footnotetext{
${ }^{6}$ M. Bechta, Wierzchowiny - historia do rewizji, „Historia Do Rzeczy” 2018, nr 2 (60); idem, Wierzchowiny - historia do rewizji, https://dorzeczy.pl/historia/54044/Wierzchowiny-historia-do-rewizji.html (dostęp: 17 II 2018).

7 Zob. np.: M. Bechta, W.J. Muszyński, op. cit., s. 326-330. Por. ibidem, s. 332-335.

${ }^{8}$ Zob. np.: ibidem, s. 334. Por. ibidem, przypis 92.
} 
w języku polskim lub rosyjskim, jak i oryginalnych dokumentów NSZ, w tym kierownictwa średniego szczebla, które zachowały się w formie rękopisów lub maszynopisów.

\section{Co o akcji na Wierzchowiny mówią dokumenty NSZ?}

Dla rekonstrukcji i opisu wydarzeń w Wierzchowinach niezwykle cenne okazują się oryginalne dokumenty NSZ z czerwca 1945 r., zachowane głównie w postaci rękopisów. Sa to: meldunek Romana Jaroszyńskiego „Romana” z 17 czerwca, raport sytuacyjny szefa AS Komendy Ziem Wschodnich (KZW)/ Komendy Okręgu (KO) XVI NSZ (Lublin) Zygmunta Wolanina „Zenona” z 21 czerwca, meldunek N.N. „Janusza” z tego samego dnia, meldunek p.o. komendanta Powiatu Chełm NSZ Wacława Kozłowskiego „Brzechwy” z 24 czerwca, w końcu artykuł zamieszczony 23 VI 1945 r. na łamach organu prasowego KZW/KO XVI NSZ (Lublin) „Szczerbiec”, w którym nie tylko przyznawano się do pacyfikacji Wierzchowin, ale też zapowiadano kolejne akcje tego typu. Należy podkreślić, że stanowią one bezsprzeczny dowód, że w akcji na Wierzchowiny brało udział wyłącznie zgrupowanie oddziałów AS/PAS „Szarego”, a życie tam straciło nie kilkunastu czy kilkudziesięciu, lecz paruset mieszkańców. Jak również to, że celem szeroko zakrojonej akcji NSZ w istocie miały być nie tylko Wierzchowiny, lecz także kilka innych okolicznych wsi ukraińskich.

17 VI 1945 r. „Roman” informował w sporządzonym odręcznie meldunku: „6 VI [19]45 r. oddziały NSZ [...] kpt. «Szarego», ppor. «Jacka» [Zbigniewa Góry], ppor. «Romana», st. sierż. «Zemsty» [Eugeniusza Walewskiego] i sierż. «Sokoła» [Bolesława Kulimowskiego] udały się na akcję na wieś ukraińska Wierzchowiny [...]. Dowództwo Narodowych Sił Zbrojnych [...] wydało rozkaz, aby mieszkańców wsi Wierzchowiny co do jednego wymordować. [...] W powyższej wsi zostało wymordowane 194 osób pochodzenia tylko ukraińskiego". 21 czerwca w odręcznym raporcie sytuacyjnym „Zenon” pisał do przełożonych: „6 VI br. Zjednoczone Oddz[iały] NSZ, tj. kpt. «Szary», «Jacek», «Sokół», «Roman» i «Zemsta», dokonały likwidacji wsi ukraińskiej Wierzchowiny, likwidując 396 osób”10. O „zlikwidowaniu wsi [Wierzchowiny - M.Z.]” donosił również w odręcznym meldunku z 21 czerwca N.N. „Janusz”" Z kolei 24 czerwca do sytuacji na terenie Powiatu Chełm NSZ po akcji na

\footnotetext{
${ }^{9}$ Archiwum Instytutu Pamięci Narodowej w Warszawie (dalej: AIPN), 932/1399, Archiwum rzeczowe NSZ i dowody rzeczowe (1945 r.), Meldunek Romana Jaroszyńskiego „Romana”, 17 VI 1945 r., rkps, k. 510-511.

${ }^{10}$ Ibidem, Archiwum rzeczowe NSZ i dowody rzeczowe (1945 r.), Raport sytuacyjny szefa AS KZW/KO XVI NSZ (Lublin) Zygmunta Wolanina „Zenona”, 21 VI 1945 r., rkps, k. 516.

${ }^{11}$ Ibidem, Archiwum rzeczowe NSZ i dowody rzeczowe (1945 r.), Meldunek N.N. „Janusza”, 21 VI 1945 r., rkps, k. 521.
} 
Wierzchowiny i do osoby Jaroszyńskiego odniósł się w odręcznym meldunku „Brzechwa”: „Z rozmów moich z rannymi i rozbitkami [spod Huty, gdzie 10 VI 1945 r. doszło do tragicznego dla NSZ starcia z grupa operacyjna wojsk NKWD i UB - M.Z.] dowiedziałem się, że po Wierzchowinach wódzia lała się strumieniami. Do okazji posłużyło przybycie małżonki «Romana». Odnośnie tego pana nabrałem przekonania, że jest to bandzior nie krępujący się niczem. Zdolny do mokrej roboty na bezbronnych Ukraińcach i Polakach. Za czas jego pobytu w rejonie «B» zdążył już narobić świństw. [...] Proszę o spowodowanie, by wszystkie oddziały AS opuściły teren powiatu [...] i to możliwie jak najszybciej”"12.

Niewygodne fragmenty tych źródeł sa w książce Mariusza Bechty i Wojciecha J. Muszyńskiego skrzętnie pomijane. W wyobrażeniu obu Autorów istnieją bowiem, jak wspomniano, jedynie w formie odpisów, które miały być sporządzone na użytek propagandy komunistycznej z jakoby poprawionych albo spreparowanych przez UB lub NKWD oryginalnych dokumentów NSZ, a w związku z tym są dla nich mało wiarygodne. Dokumenty te - oryginalne rękopisy oraz ich maszynowe odpisy sporządzone na użytek wewnętrzny przez komunistyczny aparat represji - znajdują się w Archiwum IPN w Warszawie.

Jedynym dokumentem NSZ odnoszącym się do akcji na Wierzchowiny, występującym wyłącznie w formie odpisu, jest raport terenowego dowódcy AS KO XVI NSZ (Lublin) Mieczysława Pazderskiego „Szarego” do bezpośredniego przełożonego Zygmunta Wolanina „Zenona” z 9 VI 1945 r. Czytamy w nim m.in. o zamiarze pacyfikacji kilku ukraińskich wsi na trasie przemarszu zgrupowania „Szarego” i „wycięciu” przez partyzantów NSZ w miejscowości Wierzchowiny 194 mieszkańców narodowości ukraińskiej ${ }^{13}$. Raport „Szarego" powstał w czasie postoju jego zgrupowania we wsi Huta, a następnie 12 czerwca z polecenia Romana Jaroszyńskiego dostarczony został do Lublina wraz z Aliną Blaszyńską „Kalina”, łączniczka „Zenona” i „Szarego”, która dwa dni wcześniej odniosła rany w starciu w Hucie. Prawdopodobnie jeszcze tego samego dnia dokument ten trafił w ręce Władysława Żwirka „Wysokiego”, sekretarza Tymczasowej Narodowej Rady Politycznej Ziem Wschodnich (TNRP ZW) i jednocześnie szefa Oddziału I (organizacyjnego) KZW/KO XVI NSZ ${ }^{14}$. Niestety jego oryginał do tej pory nie został odnaleziony.

Również 23 VI 1945 r. na łamach „Szczerbca” przyznawano, że do pacyfikacji Wierzchowin przez zgrupowanie AS/PAS NSZ „Szarego” doszło w odpowiedzi

${ }^{12}$ Ibidem, Archiwum rzeczowe NSZ i dowody rzeczowe (1945 r.), Meldunek p.o. komendanta Powiatu Chełm NSZ Wacława Kozłowskiego „Brzechwy”, 24 VI 1945 r., rkps, k. 251-252.

${ }^{13}$ AIPN, MBP NSZ, 73, Raport sytuacyjny dowódcy AS KO XVI NSZ (Lublin) Mieczysława Pazderskiego „Szarego” do szefa AS KZW/ KO XVI Zygmunta Wolanina „Zenona”, 9 VI 1945 r., odpis, mps, k. 3.

${ }^{14}$ Z. Leszczyńska, Jak rozbito Lubelska Komendę Narodowych Sit Zbrojnych w lipcu 1945 roku, Lublin 2005, mps, w zbiorach autora, s. 3. 
na „zabużańskie mordy, dokonywane na bezbronnej polskiej ludności” ${ }^{15}$. Treść artykułu w „Szczerbcu” wykazuje raczej nieprzypadkowa zbieżność z rozkazem wydanym 20 V 1945 r. przez szefa sztabu KZW/KO XVI Zygmunta Roguskiego „Kacpra”, dotyczacym „rozpoczęcia likwidowania band ukraińskich na terenie wschodniej i południowej części powiatu Hrubieszów”, a ponadto z raportem „Szarego” z 9 czerwca oraz zeznaniami „Zenona” z 1 i 3 X 1945 r., z których wynika, że „ «Henryk» [Jan Morawiec, I wiceprezes TNRP ZW i jednocześnie do marca 1945 r. szef Oddziału I KZW/KO XVI - M.Z.] wraz z «Wysokim» wydali rozkaz na likwidację wielu wsi ukraińskich, między innymi na Wierzchowiny" ${ }^{16}$. W tym ostatnim rozkazie obok Wierzchowin wymienione zostały także wsie: Krupe, Kasiłan, Żmudź i Matcze ${ }^{17}$. Nie bez znaczenia jest również fakt, że siedziba redakcji „Szczerbca” mieściła się w Puchaczowie ${ }^{18}$ i że właśnie tę miejscowość Wolanin wymienił w swoich zeznaniach w kontekście procesu decyzyjnego dotyczącego akcji przeciwko wsiom ukraińskim w powiatach krasnostawskim, chełmskim i hrubieszowskim planowanych w KZW/ KO XVI od drugiej połowy maja 1945 r. Czytamy w nich, że „Wysoki” był „na koncentracji [...] przed akcją wierzchowińską u «Szarego», zdaje się, że w Puchaczowie" 19 .

\section{Jak Autorzy Przeciwko Pax Sovietica... ukazują zniekształcony obraz działalności NSZ na wschodniej Lubelszczyźnie w pierwszej połowie $1945 \mathrm{r}$.}

Mam tu na myśli fragmenty zeznań Zygmunta Wolanina „Zenona” złożonych w Wojewódzkim Urzędzie Bezpieczeństwa Publicznego (WUBP) w Lublinie w październiku 1945 r., w których była mowa o wytycznych góry dla oddziałów AS, w tym o rabunkach i mordach popełnianych na przedstawicielach mniejszości narodowych (Ukraińcach i Żydach). Mariusz Bechta i Wojciech J. Muszyński sugeruja, że tego rodzaju zeznania musiały być wymuszane stosowanymi w czasie śledztwa torturami, ale jednocześnie inne ich fragmenty - odnoszace się do struktury NSZ, funkcji pełnionych w organizacji przez poszczególnych konspiratorów i w końcu zwalczania przedstawicieli oraz sympatyków władzy komunistycznej w Polsce „lubelskiej” czy Sowietów - już

${ }^{15}$ M. Bechta, W.J. Muszyński, op. cit., s. 166.

${ }^{16}$ AIPN w Lublinie (dalej: AIPN Lu), 20/88, Akta sprawy Adama Korkosza, Protokół przesłuchania podejrzanego Zygmunta Wolanina w WUBP w Lublinie, 1 X 1945 r., k. $73 \mathrm{v}-74$.

${ }_{17}$ Ibidem, Akta sprawy Adama Korkosza, Protokół przesłuchania podejrzanego Zygmunta Wolanina w WUBP w Lublinie, 3 X 1945 r., k. 75v-76.

${ }_{18}$ M. Panecki „Mat”, Historia konspiracyjnego „Szczerbca”, https://nsz.com.pl/index.php/ artykuly-i-opracowania/33-historia-konspiracyjnego-szczerbca (dostęp: 17 II 2018).

19 AIPN Lu, 20/88, Akta sprawy Adama Korkosza, Protokół przesłuchania podejrzanego Zygmunta Wolanina w WUBP w Lublinie, 1 X 1945 r., k. 73v-74. 
bez najmniejszych zastrzeżeń uznają za wiarygodne, gdyż mówią o czynach traktowanych przez nich jako chwalebne. A oto jak w świetle zeznań Wolanina prezentują się poglądy, decyzje i czyny, które trudno określić jako przynoszące chlubę NSZ. Na przykład w czasie przesłuchania z 1 X 1945 r. powody swojej „antydemokratycznej” działalności „Zenon” wyjaśniał raczej w sposób niewymuszony, m.in. przekonaniem, że w rządzie komunistycznym w Polsce „decydujący głos mają Żydzi”. W dalszej jego części szczegółowo opisywał wytyczne KZW/KO XVI dotyczace m.in. wystapień oddziałów AS przeciwko przedstawicielom mniejszości narodowych: „Pod koniec marca 1945 r. lub na początku kwietnia $1945 \mathrm{r}$. pojechałem do Chełma na odprawę. Na odprawie «Henryk» i «Wysoki» rozkazali przystapić do intensywnej pracy likwidowania, czyli zabijania Ukraińców, Żydów, volksdeutschów i pracowników Bezpieczeństwa. Po odprawie wróciłem do Krasnegostawu, zaś rozkazy zostały wysłane bezpośrednio do oddziałów z komendy okręgu «NSZ», podpisane przez «Wujka» [Tadeusza Zielińskiego, komendanta KZW/KO XVI - M.Z.] lub "Wysokiego»" ${ }^{20}$. Zeznania Wolanina, dotyczace przeprowadzania przez podległe mu oddziały AS akcji likwidacyjnych m.in. na Ukraińcach i Żydach, potwierdza rozkaz nr 5 wydany 1 VI 1945 r. przez Wacława Kozłowskiego „Brzechwę”. Zabraniał on „kom[endantom] rejonów i samodzielnych placówek wykonywania jakichkolwiek akcji likwidacyjnych w stosunku do Ukraińców, Żydów, Sowietów, NKWD i milicji”, gdyż w NSZ „do tego celu służą tylko oddziały AS”21. W odniesieniu do kategorii ofiar akcji likwidacyjnych oddziałów AS rozkaz „Brzechwy” wykazuje zbieżność ze złożonymi w czasie śledztwa w UB zeznaniami „Zenona”.

Wzorcowym przykładem zniekształcania przez Bechtę i Muszyńskiego niewygodnych treści pochodzących z wykorzystanych w książce dokumentów archiwalnych są zeznania wspomnianego już Wolanina. O zadaniach i wskazówkach politycznych przekazanych 28 IV 1945 r. dowódcom oddziałów AS (,Sokołowi”, „Jackowi” i „Romanowi”) przez Jana Morawca „Henryka” lub Władysława Żwirka „Wysokiego” Autorzy pisali, powołując się na zeznania „Zenona” z 3 X 1945 r.: „Oddziały miały likwidować funkcjonariuszy UB i MO, atakować i rozbijać więzienia, areszty oraz konwoje, ponadto uniemożliwiać Ukraińcom wywożenie mienia zrabowanego polskim sasiadom za Bug. Polecano też zgromadzić zapasy żywności na czas trzech miesięcy" (s. 322). W rzeczywistości treść zeznań Wolanina w kilku miejscach znacząco różni się od ich sparafrazowanej, w istocie zmanipulowanej wersji przedstawionej w książce Przeciwko Pax Sovietica... Czytamy w nich bowiem:

${ }^{20}$ Ibidem, Akta sprawy Adama Korkosza, Protokół przesłuchania podejrzanego Zygmunta Wolanina w WUBP w Lublinie, 1 X 1945 r., k. 72-72v.

${ }^{21}$ AIPN, 932/1399, Archiwum rzeczowe NSZ i dowody rzeczowe (1945 r.), Rozkaz ogólny nr 5 p.o. komendanta Powiatu Chełm NSZ dotyczący współpracy NSZ i DSZ w terenie, 1 VI 1945 r., k. 258. 
„[...] przeszkadzać Ukraińcom wywozić swoje mienie, zaopatrzyć się w żywność drogą rabunku na okres trzech miesięcy, dokonywać napadów na konwoje, areszty i więzienia celem odbicia więźniów, zabijać ludzi, którzy działają na szkodę organizacji, tj. członków Bezpieczeństwa, Milicji, Żydów"22. W tym samym protokole przesłuchania Wolanin doprecyzował zreszta, że około połowy maja 1945 r. Władysław Żwirek „Wysoki” wydał oddziałom AS rozkaz, aby dokonywały „napadów na Ukraińców wyjeżdżających na wschód”. Wspominał również o meldunkach „Jacka”, „Romana”, „Zemsty” i „Sokoła” dotyczących działalności podległych im oddziałów w okresie „od początku marca do około 25 kwietnia [1945 r.]”. Była w nich mowa o „napadach rabunkowych za żywnością" i zabiciu w tym czasie „około 60 osób pochodzenia ukraińskiego, niemieckiego i żydowskiego”23. W zeznaniach z 1 X 1945 r. „Zenon” wyjaśniał natomiast, że rabunków dokonywano „na ludności ukraińskiej”24.

$\mathrm{W}$ trzech sparafrazowanych fragmentach dokumentu mamy zatem do czynienia z trzema istotnymi zmianami dokonanymi przez obu Autorów: nieuprawnionym dopowiedzeniem dotyczącym mienia ukraińskiego, intencjonalnym pominięciem osób pochodzenia żydowskiego jako jednej z kategorii ofiar akcji likwidacyjnych przeprowadzanych przez oddziały AS oraz problemu rabunków dokonywanych przez nie na szkodę miejscowej ludności ukraińskiej, która w tym czasie przesiedlana była z Polski „lubelskiej” do USRS.

Powołując się na protokół przesłuchania „Zenona” z 11 X 1945 r., Mariusz Bechta i Wojciech J. Muszyński stwierdzili: „Oficerowie z komendy XVI Okręgu NSZ przez dłuższy czas nie wiedzieli, co naprawdę stało się ze zgrupowaniem kpt. «Szarego». Najprawdopodobniej 9 czerwca [1945 r. - M.Z.] w cukierni «Miraż» w Lublinie doszło do spotkania «Wysokiego» z «Zenonem». [...] Na tym samym spotkaniu «Wysoki» poinformował (nie zdajacc sobie sprawy z niekorzystnego rozwoju zdarzeń), że «Bartek» [Leon Opawski, szef Oddziału III (szkoleniowego) KZW/KO XVI - M.Z.] ma objechać oddziały NSZ w terenie" (s. 347). A oto, co 1 X 1945 r. zeznał na ten temat Wolanin: „Po akcji wierzchowińskiej w czerwcu 1945 r., daty nie pamiętam, spotkałem «Wysokiego» na punkcie kontrolnym w Mirażu, gdzie rozmawialiśmy na temat Wierzchowin. W trakcie rozmowy «Wysoki» wyraził zadowolenie

22 AIPN Lu, 20/88, Akta sprawy Adama Korkosza, Protokół przesłuchania podejrzanego Zygmunta Wolanina w WUBP w Lublinie, 3 X 1945 r., k. 75v.

${ }^{23}$ Ibidem, k. 76v. Chodzi o rozstrzelanie z rozkazu „Szarego” m.in. sześciu niemieckich żołnierzy zbiegłych z obozu jenieckiego pod Chełmem, którzy na pewien czas dołaczyli do oddziału AS „Szarego” lub „Zemsty”. Zob. Archiwum Państwowe w Lublinie (dalej: APL), NSZ, 12, Meldunek kpt. „Szarego” do Komendy Okręgu XVI NSZ (Lublin), 25 IV 1945 r., k. 19. Por. S. Nieworaj, Wspomnienia z lat 1939-1947 oraz komentarze do lat wcześniejszych i późniejszych, oprac. I. Czmuda, wspomnienia zgłoszone na konkurs „Chłopskiej Drogi” z okazji dwudziestolecia PRL, b.d., mps, w zbiorach autora, s. 17.

${ }^{24}$ AIPN Lu, 20/88, Akta sprawy Adama Korkosza, Protokół przesłuchania podejrzanego Zygmunta Wolanina w WUBP w Lublinie, 1 X 1945 r., k. 74. 
z roboty «Szarego» w Wierzchowinach, mniej więcej tymi słowami: «Dobra robota, lubię taki szum!»"25. W świetle ustaleń Zofii Leszczyńskiej do spotkania tego mogło dojść najprawdopodobniej dopiero po 12 VI 1945 r. Wtedy „Wysoki” miał już szczegółową wiedzę o działaniach zgrupowania „Szarego” w dniach 6-10 czerwca, czyli o akcji na Wierzchowiny i klęsce w Hucie. Jak już wspomniano, pochodziła ona z meldunku „Szarego” (9 czerwca) przywiezionego do Lublina przez łączniczkę „Kalinę” (12 czerwca) i prawdopodobnie też z uzyskanych bezpośrednio od niej informacji.

Zdarza się, że Bechta i Muszyński starają się ukryć narodowość ofiar NSZ pod hasłem „oficerowie polityczni”, np. w odniesieniu do pięciu berlingowców pochodzenia żydowskiego rozstrzelanych po akcji w Kaniach przez oddział AS „Szarego” (s. 324). Posłużyli się takim sformułowaniem, mimo że w meldunku Pazderskiego do KO XVI NSZ z 25 IV 1945 r., na który powołali się w książce, wyraźnie mówi się, że dzień wcześniej (po rozbrojeniu bez walki pięćdziesięcioosobowego oddziału WP w majątku Kanie w pobliżu Chełma) „aresztowano 5 Żydów, których o świcie rozstrzelano"26.

Mariusz Bechta i Wojciech J. Muszyński nie przekonują również do tezy, jakoby ofiarami akcji likwidacyjnych oddziałów AS NSZ były jedynie „osoby współpracujące z reżimem komunistycznym” czy działające „wówczas [w 1945 r. - M.Z.] lub wcześniej [w czasie okupacji niemieckiej? - M.Z.], na szkodę polskich struktur podziemnych" (s. 320). Lansowanej przez nich tezie przeczą bowiem oryginalne dokumenty NSZ z przedwiośnia i wiosny 1945 r. Na przykład w meldunku Bolesława Kulimowskiego „Sokoła” mowa jest o zabiciu przez jego podkomendnych w niespełna miesiąc (23 II - 20 III 1945 r.) 29 osób: 4 pochodzenia żydowskiego i 25 ukraińskiego, w tym 8 kobiet. Wynika z tego, że statystycznie każdego dnia partyzanci „Sokoła” zabijali jakiegoś Ukraińca lub Żyda. Jak czytamy w dokumencie NSZ, ofiary zostały „zlikwidowane wyrokiem śmierci [4 Żydów i 8 Ukrainek - M.Z.]”, gdyż „szkodziły Polakom lub pracowały na ich szkodę”, oraz „częściowo podczas akcji na transporty, a częściowo podczas specjalnej egzekucji [17 Ukraińców, przesiedleńców do USRS oraz osób powracajacych z robót przymusowych lub obozów koncentracyjnych w Niemczech - M.Z.]”27. W meldunku tym „Sokół” odwoływał się do rozkazu KZW/KO XVI z 23 II 1945 r., który prawdopodobnie miał związek z akcją o kryptonimie „Za Bugiem”.

W opinii Bechty i Muszyńskiego ofiarami szeregu akcji likwidacyjnych przeprowadzonych wiosną 1945 r. także przez oddział AS „Jacka” było „wielu działaczy PPR pochodzenia polskiego i ukraińskiego oraz zwykłych kryminalistów" (s. 321). Ciekawe, do której z wymienionych kategorii Autorzy

\footnotetext{
${ }^{25}$ Ibidem, k. 73v-74.

${ }^{26}$ APL, NSZ, 12, Meldunek kpt. „Szarego” do Komendy Okręgu XVI NSZ (Lublin), 25 IV 1945 r., k. 19.

27 Ibidem, Raport dowódcy oddziału AS plut. „Sokoła” (Oleś B 2 XVI), marzec 1945 r., k. 3.
} 
zaliczyliby byłego naczelnego kapelana prawosławnego WP ks. Bazylego Martysza oraz jego brzemienną córkę i kilkuletnią wnuczkę, którzy $4 \mathrm{~V}$ 1945 r. zostali napadnięci we własnym domu w Teratynie przez partyzantów „Jacka”. Księdza Martysza po skatowaniu dobito strzałem z pistoletu. Jego córkę dotkliwie pobito, w następstwie czego poroniła. Mała dziewczynkę zaś sterroryzowano, zamykając na strychu na czas „specjalnej egzekucji” wykonywanej przez partyzantów NSZ na jej dziadku i matce ${ }^{28}$.

W zasadzie jedyną autorską i jednocześnie główną w książce Mariusza Bechty i Wojciecha J. Muszyńskiego tezą dotyczącą wypadków z 6 VI 1945 r. jest sugestia, że współodpowiedzialność za mord w Wierzchowinach spoczywa także na innych niż NSZ odłamach podziemia antykomunistycznego. Swoje podejrzenia Autorzy Przeciwko Pax Sovietica... kieruja na bezpośrednia kontynuatorkę AK - Delegaturę Sił Zbrojnych na Kraj (DSZ) ${ }^{29}$.

Dla Autorów recenzowanej publikacji bez znaczenia wydaje się fakt, że w żadnym ze znanych dokumentów NSZ dotyczaccych akcji na Wierzchowiny nie znajdziemy najmniejszej wzmianki o jakimkolwiek oddziale poakowskiego podziemia, który miałby brać w niej udział. Mowa jest w nich wyłacznie o oddziałach tworzących zgrupowanie AS/PAS: Mieczysława Pazderskiego „Szarego”, Romana Jaroszyńskiego „Romana”, Zbigniewa Góry „Jacka”, Bolesława Kulimowskiego „Sokoła” i Eugeniusza Walewskiego „Zemsty”.

Wywołaniu wrażenia, że jakiś poakowski oddział dołączył do zgrupowania NSZ przed akcją na Wierzchowiny, aby wziąć w niej udział, miało najpewniej służyć zamieszczenie w książe Przeciwko Pax Sovietica... nieprawdziwej informacji, jakoby w nocy z 5 na 6 VI 1945 r. w kierunku wsi Wierzchowiny „w ślad za zgrupowaniem NSZ [...] podążał od Rejowca oddział AK-DSZ Stanisława Sekuły «Sokoła»" (s. 333). Przeczy jej bowiem treść meldunku N.N. „Janusza” z 21 VI 1945 r., w którym jest co prawda mowa, że do zetknięcia się partyzantów „Szarego” z oddziałem AK/DSZ „Sokoła” doszło, lecz nie $\mathrm{w}$ drodze do Wierzchowin, ale w nocy z 7 na 8 czerwca, kiedy zgrupowanie NSZ zmierzało z lasu w pobliżu wsi Buśno do Huty: „Wieczorem [7 czerwca - M.Z.] opuściliśmy lasek [w pobliżu Buśna - M.Z.] i o północy dotarliśmy do Huty. Po drodze minęliśmy oddział «Sokoła» z AK, który aż zza Rejowca ciagną za nami”" ${ }^{30}$. Warto w tym miejscu wspomnieć, że co najmniej do końca lat dziewięćdziesiątych XX w. poakowski oddział Sekuły uznawany bywał przez niektórych badaczy za grupę prowokacyjną UB.

${ }^{28}$ Ibidem, Raport dowódcy oddziału AS „Jacka” z egzekucji Ukraińca Bazylego Martysza, po 4 V 1945 r., k. 34; K. Mazurek, Życie i działalność księdza Bazylego Martysza, Warszawa 2009, mps, w zbiorach autora, s. 70-72; Relacja Ireny Martysz-Mazurek, 21 II 2016 r., nagranie, w zbiorach Michała Godlewskiego; M. Zajączkowski, Pod znakiem króla Daniela. OUN-B i UPA na Lubelszczyźnie 1944-1950, Lublin-Warszawa 2016, s. 167-168.

${ }^{29}$ M. Zajączkowski, W obronie Armii Krajowej, „Historia Do Rzeczy” 2018, nr 6 (64).

${ }^{30}$ AIPN, 932/1399, Archiwum rzeczowe NSZ i dowody rzeczowe (1945 r.), Meldunek N.N. „Janusza”, 21 VI 1945 r., rkps, k. 521. 
Obarczaniu zamojskiej AK/DSZ współodpowiedzialnością za mord na mieszkańcach Wierzchowin służyło natomiast przywoływanie odpowiednio dobranych fragmentów zeznań byłego bechowca z powiatu krasnostawskiego, Adama Korkosza „Brzozy”, uczestnika akcji na Wierzchowiny w szeregach zgrupowania NSZ. W ocenie Mariusza Bechty i Wojciecha J. Muszyńskiego zeznania te miały dowodzić, że w akcji brał udział także poakowski oddział Bolesława Sobieszczańskiego „Pingwina”. Autorzy pomijaja jednak wiele innych dokumentów znajdujących się w aktach sprawy i aktach śledczych dotyczących Korkosza, które wyraźnie temu przecza ${ }^{31}$. Podchodząc do zeznań Korkosza bezkrytycznie, Bechta i Muszyński uznali, że wymieniany w nich N.N. „Pingwin” to na pewno podkomendny Józefa Śmiecha „Ciaga” - Bolesław Sobieszczański. Uczynili tak, choć Sobieszczański zaprzeczył, by kiedykolwiek poznał Adama Korkosza „Brzozę”. Warto zaznaczyć, że nawet oficerowie śledczy UB mieli poważne wątpliwości co do prawdziwej tożsamości N.N. „Pingwina”, czego dowodzi notatka sporządzona 25 II 1950 r. przez naczelnika Wydziału III WUBP w Lublinie. Odnośnie do dowódcy jednego z oddziałów bioracych udział w akcji na Wierzchowiny, który posługiwał się pseudonimem Pingwin, stwierdzano w niej, że „niemożliwością jest ustalić” jego tożsamość oraz przynależność organizacyjna, „gdyż pod takim pseudonimem na terenie woj. lubelskiego było kilku dowódców band NSZ, AK, a później WiN"32. Bechta i Muszyński nie podzielają wątpliwości pracowników UB, jednak nie przybliżają też czytelnikowi, jak rozstrzygnęli rozbieżności w zeznaniach Korkosza i Sobieszczańskiego ${ }^{33}$. Prawdopodobnie ich uwadze umknęło również, że w innym miejscu książki na podstawie dokumentu NSZ pisali, iż już w połowie maja 1945 r. podkomendni „Ciaga” wykazywali wrogi stosunek do partyzantki NSZ (s. 327). Należy podkreślić, że wrogość ta w dużej mierze spowodowana była napadami eneszetowców na miejscowa ludność ukraińską w kontrolowanej przez AK/DSZ północnej i zachodniej części powiatu hrubieszowskiego. O rozbrajaniu pojedynczych członków oddziału AS „Sokoła” przez żołnierzy AK/DSZ „Ciaga” po przeprowadzonej przez NSZ akcji na Wierzchowiny jest też mowa w znanym Autorom - choć jedynie w formie odpisu maszynowego - odręcznym meldunku wspomnianego już N.N. „Janusza” ${ }^{34}$. Kroki podjęte wobec eneszetowców przez ludzi „Ciaga”

${ }^{31}$ M. Bechta, W.J. Muszyński, op. cit., s. 332-335. Por. AIPN Lu, 20/88, Akta sprawy Adama Korkosza; AIPN Lu, 06/133, Akta śledcze dotyczące Adama Korkosza.

32 AIPN Lu, 20/88, Akta sprawy Adama Korkosza, Notatka naczelnika Wydziału III WUBP w Lublinie, 25 II 1950 r., k. 122.

${ }_{33}$ AIPN Lu, 06/133, Akta śledcze dotyczące Adama Korkosza, Protokół przesłuchania podejrzanego Adama Korkosza w WUBP w Lublinie, 30 VI 1949 r., k. 21. Por. ibidem, Akta śledcze dotyczące Adama Korkosza, Protokół przesłuchania świadka Bolesława Sobieszczańskiego w WUBP w Lublinie, 23 IX 1949 r., k. 26-27.

${ }^{34}$ AIPN, 932/1399, Archiwum rzeczowe NSZ i dowody rzeczowe (1945 r.), Meldunek N.N. „Janusza”, 21 VI 1945 r., rkps, k. 521-521v. 
wynikały najpewniej z wytycznych zamojskiego inspektora AK/DSZ Mariana Gołębiewskiego „Irki” z 3 VI 1945 r., o których Bechta i Muszyński napisali bardzo oględnie, że dotyczyły jedynie kategorycznego zakazu „nawiązywania jakichkolwiek kontaktów z NSZ" przez żołnierzy AK/DSZ (s. 327). Niemniej w powtórzonym dwa dni później (5 VI 1945 r., czyli w przeddzień akcji na Wierzchowiny) rozkazie komendanta hrubieszowskiego obwodu AK/DSZ Józefa Dąbrowskiego „Azji”, odwołującym się do poprzednich rozkazów inspektora „Irki”, czytamy: „Zabraniam wszelkich kontaktów z NSZ. Wszelkie objawy rabunków wspomnianych traktować i zwalczać jako bandytyzm"35. Wydaje się zatem, że AK/DSZ mogła potraktować akcję oddziałów NSZ na Wierzchowiny jako przejaw bandytyzmu.

Pomimo powyższych faktów Bechta i Muszyński stwierdzili: „Z cała pewnością wczesnym popołudniem 6 czerwca 1945 r. oddziały NSZ [«Szarego», «Jacka», «Romana», «Zemsty», «Sokoła» - M.Z.], i AK-DSZ [mowa tu o oddziałach Bolesława Sobieszczańskiego "Pingwina», Romana Szczura «Urszuli», Stanisława Kulika «Tarzana» oraz Konstantego Piotrowskiego «Zagłoby», na podstawie zeznań Korkosza błędnie określanego przez Autorów «Jastrzębiem» - M.Z.], być może niezależnie od siebie, działając z przeciwległych kierunków, okrążyły Wierzchowiny" (s. 332-333). Autorzy uczynili tak, mimo że w innym miejscu ksiażki pisali - cytując jako dowód meldunek „Szarego” do KO XVI NSZ (Lublin) z 20 V 1945 r. - o ,agresywnej i wrogiej postawie”, jaka 18 maja, a więc na krótko przed akcją na Wierzchowiny, żołnierze oddziału chełmskiej AK/DSZ Konstantego Piotrowskiego „Zagłoby” (a nie „Jastrzębia”) przyjęli wobec partyzantów z oddziału NSZ „Szarego” zmierzających „na rekwizycje do wsi ukraińskiej w powiecie lubartowskim" (s. 328).

Całego tego zamieszania dałoby się najpewniej uniknacć, gdyby Autorzy zapoznali się przynajmniej z podstawowa, ogólnie dostępną literatura przedmiotu i wykorzystali ją w pracy. Wystarczy na przykład przewertować książkę Jana Turowskiego Historia OP 9 lub zajrzeć do akt procesowych Tadeusza Kuncewicza „Podkowy”, , aby podtrzymywana przez nich teza o współudziale oddziałów AK/DSZ „Pingwina” i „Urszuli” w mordzie wierzchowińskim, wysnuta na podstawie potraktowanych bardzo selektywnie i bezkrytycznie akt sprawy Korkosza, legła w gruzach. W pracy Turowskiego czytamy bowiem: „Na odprawie w Szperówce, pod koniec maja [1945 r. - M.Z.] inspektor «Irka» w obecności komendanta obwodu [zamojskiego - M.Z.] ppor. Michała Polaka «Żelaznego» zlecił [...] robotę [rozbicia więzienia w Chełmie - M.Z.] «Podkowie». W pierwszych dniach czerwca na koncentrację w Pańskiej Dolinie stawiły się plutony «Mafa» [Mariana Mijalskiego - M.Z.] i «Urszuli»; po drodze miał dołączyć «Pingwin». W Tuczępach koło Grabowca, pod presja miejscowych władz AK, marsz na Chełm został wstrzymany. Powodem tego

${ }_{35}$ APL, WiN, 159, Obwód Hrubieszów, Rozkaz komendanta obwodu, 5 VI 1945 r., k. 6.

${ }^{36}$ Zob. AIPN Lu, 17/1254, Akta sprawy Tadeusza Kuncewicza. 
była gigantyczna operacja sił bezpieczeństwa i NKWD przeciwko oddziałom NSZ kpt. Mieczysława Pazderskiego «Szarego», który 6 czerwca spacyfikował ukraińską prokomunistyczną wieś Wierzchowiny koło Siennicy Różanej. Na styku 3 powiatów trwała pożoga...”37

Warto dodać, że o tym, iż wczesną wiosna 1945 r. lubelskie struktury AK/DSZ odmówiły podjęcia jakiejkolwiek współpracy z oddziałami AS NSZ „Szarego” w walce przeciwko Ukraińcom, pisał w swoim pamiętniku również Zdzisław Broński „Uskok”, jeden z najsłynniejszych dowódców poakowskiego podziemia na Lubelszczyźnie ${ }^{38}$.

Znamienne, że w podrozdziale książki poświęconym propagandzie podziemia narodowego, w kontekście wspomnianego już artykułu zamieszczonego 23 VI 1945 r. na łamach „Szczerbca”, w którym NSZ przyznawały się do Wierzchowin, Bechta i Muszyński także stwierdzają bez ogródek: „Wierzchowiny stały się zatem symbolem wymierzenia sprawiedliwości, zarówno za okrucieństwa, których dopuszczały się bandy UPA [Ukraińskiej Armii Powstańczej - M.Z.], jak i za pomoc, jakiej Ukraińcy udzielali reżimowi warszawskiemu i Sowietom w zwalczaniu polskiego podziemia niepodległościowego" (s. 166) ${ }^{39}$. W świetle powyższej konstatacji zdumiewa upór, z jakim obaj Autorzy starali się na następnych stronach swojej książki udowadniać AK/DSZ współudział w zbrodni NSZ na ukraińskiej ludności Wierzchowin, czyniąc to w dodatku wbrew faktom i dokumentom (także proweniencji NSZ), na które tak często się powoływali.

Należy jeszcze raz podkreślić, że wbrew zaprezentowanej przez Mariusza Bechtę i Wojciecha J. Muszyńskiego tezie dostępny materiał źródłowy (nota bene bardzo dobrze znany obu Autorom) nie pozwala na wysnucie wniosków, że AK/DSZ była współodpowiedzialna za mord na ukraińskich cywilach w Wierzchowinach. Faktu tego nie zmienią również dywagacje na temat wielkości odsetka, jaki w zgrupowaniu AS/PAS „Szarego” stanowili dezerterzy z WP oraz dawni bechowcy czy akowcy, w tym byli żołnierze 27 Wołyńskiej Dywizji Piechoty AK lub po prostu Polacy pochodzący z Wołynia, którzy doświadczyli traumy antypolskich akcji Organizacji Ukraińskich Nacjonalistów Stepana Bandery (OUN-B) i UPA z lat 1943-1944. Wiosna 1945 r. nikt z nich nie był bowiem członkiem AK/DSZ, a w akcji na Wierzchowiny brali udział pod szyldem NSZ i na rozkaz KZW/KO XVI. W związku z powyższym odpowiedzialność za zbrodnię popełnioną na mieszkańcach Wierzchowin spoczywa wyłącznie na barkach tej organizacji i jej kierownictwa.

${ }^{37}$ J. Turowski, Historia OP 9, wybór i oprac. D. Górny, W. Seroka, A. Skiba, Zamość 2017, s. 73 .

${ }^{38}$ Z. Broński „Uskok”, Pamiętnik (wrzesień 1939 - maj 1949), oprac. S. Poleszak i in., LublinWarszawa 2015, s. 134-135.

${ }^{39} \mathrm{~W}$ tym fragmencie zwraca uwagę zaangażowany język Autorów i użycie przez nich sformułowania „bandy UPA”, charakterystycznego dla języka propagandy z PRL. 


\section{Rzekomi współsprawcy zbrodni: okoliczni polscy chłopi, żołnierze WP i Wojsk Pogranicznych NKWD, milicjanci i członkowie grupy prowokacyjnej UB...}

Obok podziemia poakowskiego wina za współudział w brutalnym mordzie w Wierzchowinach Mariusz Bechta i Wojciech J. Muszyński obarczaja m.in. chłopów z sąsiednich polskich wsi, a dokładniej „grupy mężczyzn uzbrojonych w ostre narzędzia: siekiery, widły i szpadle, które plądrowały domy i w niezwykle okrutny sposób zabijały broniących swego dobytku ludzi” (s. 337). Autorzy zdaja się w tym fragmencie sugerować istnienie polskiego odpowiednika ukraińskich siekierników z Wołynia $1943 \mathrm{r}$.

Teoria o współudziale okolicznych polskich chłopów w zamordowaniu ukraińskich mieszkańców Wierzchowin nie jest autorską teza Bechty i Muszyńskiego, ale ustaleniem Oddziałowej Komisji Ścigania Zbrodni przeciwko Narodowi Polskiemu w Lublinie (s. 337-338, przypis 103). Obaj chętnie się na nie powołuja, zaznaczając przy tym jednak, że nie satysfakcjonuje ich w pełni, ponieważ nie rozwiewa wszelkich wątpliwości, które narosły „przez ostatnie półwiecze".

W recenzowanej monografii czytamy również o współudziale w zbrodni wierzchowińskiej żołnierzy WP i Wojsk Pogranicznych NKWD czy pracowników UB i milicjantów. Wystarczy jedynie wspomnieć, że z pola widzenia zniknęła - a raczej odsunięta została na dalszy plan - lansowana jeszcze do niedawana teza, że mordu we wsi dokonała grupa prowokacyjna UB po opuszczeniu wsi przez zgrupowanie NSZ. Obecnie została ona zastapiona rozwiniętą wersją wypadków o grupie ubeckich prowokatorów w samym zgrupowaniu „Szarego”, której rzekomo mogło „zależeć na zbrutalizowaniu przebiegu akcji”"

Nie sposób oprzeć się wrażeniu, że w książce Mariusza Bechty i Wojciecha J. Muszyńskiego mamy do czynienia z umyślną próbą rozmywania odpowiedzialności NSZ za popełniona zbrodnię i wydatnego umniejszenia jej skali lub też usiłowaniem jej usprawiedliwienia. Jednocześnie Autorzy przerzucają winę za mord na innych aktorów wydarzeń. Swoje stanowisko tłumaczą zawiłymi okolicznościami i niezwykle dynamicznym przebiegiem wypadków, do których 6 VI 1945 r. doszło w Wierzchowinach. Konstatuja wreszcie, że w zasadzie nie wiadomo, co się wtedy stało we wsi. Może poza jednym - że NSZ były co najwyżej współodpowiedzialne za dokonana zbrodnię, choć jakoby nie do końca wiedza, w jakim stopniu. Jednym słowem dokonują relatywizacji, stosując przy tym zabiegi łudząco przypominające metodologię przyjętą przez niektórych ukraińskich badaczy hołdujących tradycji banderowskiego podziemia w odniesieniu do pierwszych akcji antypolskich na Wołyniu z zimy 1942/1943 r. (zbrodni popełnionej 9 II 1943 r. przez partyzantkę banderowska

${ }^{40}$ M. Bechta, Wierzchowiny - historia do rewizji..., s. 66. 
na mieszkańcach Kolonii Parośla). Ukraińscy strażnicy pamięci również wychodzą z założenia, że o mordzie w Kolonii Parośla wiemy stosunkowo niewiele, poza jednym - że raczej nie dokonali jej banderowcy, lecz ktoś zupełnie inny: partyzanci pierwszej UPA Tarasa Borowcia „Bulby” (bulbowcy), niezwiązani z OUN-B okoliczni ukraińscy chłopi (siekiernicy) czy w końcu sowieccy partyzanci podszywający się pod banderowską UPA ${ }^{41}$.

\section{Czy w istocie nieznana jest liczba ofiar zbrodni w Wierzchowinach?}

Jak już wspomniano, w książce Mariusza Bechty i Wojciecha J. Muszyńskiego nie ma otwartego stwierdzenia, że zanim doszło do pacyfikacji Wierzchowin, ofiarami akcji likwidacyjnych prowadzonych przez lubelskie oddziały AS NSZ byli także Żydzi. Wybiórcze podejście obu Autorów do najnowszej literatury przedmiotu i dokumentów archiwalnych powoduje, że w ich publikacji nie znajdziemy też najmniejszej wzmianki o pomordowaniu świadków Jehowy, choć znane są nazwiska 16 ofiar będących członkami ok. dwudziestoosobowej wierzchowińskiej społeczności tego wyznania ${ }^{42}$. Mimo że książka Przeciwko Pax Sovietica... została wydana po ukazaniu się opracowań, w których o Badaczach Pisma Świętego pisano jako o jednej z kategorii ofiar akcji $\mathrm{NSZ}^{43}$, próżno w niej szukać takich informacji. Wydaje się, że kompletne zaskoczenie wynikające z ujawnienia nowych okoliczności zbrodni w Wierzchowinach oraz brak możliwości znalezienia merytorycznych argumentów do odparcia kolejnych zarzutów pod adresem partyzantów NSZ zmusiły Bechtę i Muszyńskiego do przemilczenia tego faktu.

Twierdzenie, że na bazie dostępnego materiału źródłowego nie możemy dziś określić konkretnej liczby ofiar mordu w Wierzchowinach, gdyż zachowane dokumenty zawierają różne informacje (źródła komunistyczne - 197, 202, ok. 400 ofiar; dokumenty NSZ - 194, 396 ofiar), okazuje się tylko pozornie słuszne. Nieprawdą jest bowiem, że dane te znamy jedynie z rzekomych ubeckich fałszywek (w istocie oryginalnych dokumentów NSZ), jak również

${ }^{41}$ Zob. np.: W. Wiatrowycz, Szukanie winnego, „Nowa Europa Wschodnia” 2013, nr 1 (27); S. Riabenko, Szczo stałosia w Parosli? Chto prynis smert' u polśku kołoniju na Wotyni, http://www.istpravda.com.ua/articles/2017/02/4/149517/ (dostęp: 17 II 2018).

${ }^{42}$ Archiwum Akt Nowych, MAP, 705, mf. B-1724, Pismo Przewodniczącego Krajowej Centrali Wyznania Świadków Jehowy (Badaczy Pisma Świętego) w Polsce do Departamentu Wyznaniowego Ministerstwa Administracji Publicznej w Warszawie (Zestawienie wypadków wrogich wystapień antywyznaniowych), Łódź, 18 II 1948 r., k. nlb.

${ }^{43}$ Hiobowie XX wieku. Wspomnienia Świadków Jehowy (Badaczy Pisma Świętego), oprac. K. Biliński, Wrocław 2012, s. 172; G. Motyka, Wotyń '43. Ludobójcza czystka - fakty, analogie, polityka historyczna, Kraków 2016, s. 118; M. Zajączkowski, Pod znakiem króla Daniela..., s. 174-177. 
to, że liczba ofiar była znacznie mniejsza niż 194 osoby widniejące $\mathrm{w}$ raporcie „Szarego” z 9 VI 1945 r. i meldunku „Romana” z 17 czerwca tego roku, nie wspominając już o innych dokumentach NSZ czy zeznaniach członków KZW/KO XVI, w których wymieniono nawet blisko 400 ofiar (np. w raporcie „Zenona” z 21 VI 1945 r. i jego późniejszych zeznaniach w WUBP w Lublinie z października tego roku). Ta ostania liczba jest jednak najpewniej zawyżona, gdyż wynika z nie do końca zweryfikowanych danych pochodzących z raportów dowódców NSZ niższego szczebla, które po 10 VI 1945 r. napływały z terenu do szefa AS/PAS.

Liczbę ok. 200 ofiar mordu w Wierzchowinach potwierdzają nie tyle materiały procesowe czy jakoby spreparowane przez komunistów dokumenty NSZ, co przechowywany w Archiwum Gminy Siennica Różana rejestr mieszkańców wsi i majątku Wierzchowiny oraz Wesołówka Wierzchowińska prowadzony w latach 1932-1945. Źródło to zostało poddane gruntownej analizie przez piszącego te słowa w opublikowanym w 2006 r. artykule Spór o Wierzchowiny... Czytamy w nim o znanych z imienia i nazwiska 206 mieszkańcach wsi „zmarłych” od zakończenia okupacji niemieckiej do 6 VI 1945 r. włącznie. 202 z nich było wyznania prawosławnego, a odnośnie do 4 brakuje w rejestrze adnotacji o wyznaniu (prawdopodobnie to świadkowie Jehowy, których zamordowano 16). Losy tych osób wyjaśnione zostały w rejestrze za pomoca dwóch opisów: „zmarł/a w 1945 r.” - 67 osób (64 prawosławnych, 3 o nieokreślonym wyznaniu) oraz „zmarł/a w Wierzchowinach” lub po prostu „zmarł/a” - 139 osób (138 prawosławnych, 1 o nieokreślonym wyznaniu).

Z danych zawartych w rejestrze wynika, że spośród 29 zgonów odnotowanych między 1932 a 1938 r. najwięcej przypadało na lata 1937-1938 (w sumie 12 osób). Podczas okupacji niemieckiej zmarło bądź zginęło 49 mieszkańców, z czego najwięcej w latach 1942-1943 (razem 26 osób). Jeżeli założymy, że od sierpnia $1944 \mathrm{r}$. do czerwca $1945 \mathrm{r}$. z przyczyn naturalnych zmarło ok. 10 mieszkańców Wierzchowin, to po odjęciu tej liczby od 206 „zmarłych” widniejących w rejestrze otrzymamy liczbę 196, a więc bliską przekazom z dokumentów NSZ mówiącym o 194 ofiarach $^{44}$.

W związku z powyższym wszelkie dywagacje na temat wielkości mogiły w Wierzchowinach i braku możliwości zmieszczenia w niej ok. 200 ciał zamordowanych mieszkańców wsi uważam za co najmniej niestosowne. Takie stawianie sprawy może bowiem jedynie uwłaczać pamięci ofiar tej zbrodni, a ponadto świadczyć - choć wierzę, że tak nie jest - o braku szacunku lub nawet pogardzie dla obywateli Rzeczypospolitej, którzy stracili życie z rąk współobywateli innej narodowości.

${ }^{44}$ M. Zajączkowski, Spór o Wierzchowiny. Działalność oddziałów Akcji Specjalnej (Pogotowia Akcji Specjalnej) NSZ w powiatach Chetm, Hrubieszów, Krasnystaw i Lubartów na tle konfliktu polsko-ukraińskiego (sierpień 1944 r. - czerwiec 1945 r.), „Pamięć i Sprawiedliwość” 2006, nr 1 (9), s. 290-293. 
Mimo zapowiedzi wygłaszanych na długo przed wydaniem książki oraz zamieszczanych na forach społecznościowych relacji, które dotyczyły mających przynieść „zaskakujące efekty” szeroko zakrojonych i żmudnych kwerend archiwalnych na „odcinku wierzchowińskim”, prowadzonych przez Mariusza Bechtę i wydatnie wspomagający go zespół środowiskowych researcherów, ustalenia Autorów rozczarowuja. Podczas badań miało dojść do odkrycia istnych „rewelacji” i zdemaskowania niezliczonych „matrioszek”, które jak dotąd nie pozwalały dokonać dekonstrukcji „kanonicznej” wersji wydarzeń w Wierzchowinach z 6 VI 1945 r., prezentowanej w polskiej historiografii po $1989 \mathrm{r}$. przez historyków niezwiązanych ze środowiskiem hołdującym tradycji NSZ i jakoby bezrefleksyjnie powielających ustalenia historiografii peerelowskiej. $\mathrm{W}$ istocie do niczego takiego nie doszło. Po upływie ponad 20 lat od wydania przez Grzegorza Motykę i Rafała Wnuka książki Pany i rezuny... ${ }^{45}$, blisko 20 lat od opublikowania artykułu Wierzchowiny $i$ Huta... Rafała Wnuka ${ }^{46}$ oraz monografii Polityka $i$ walka... Krzysztofa Komorowskiego ${ }^{47}$, w końcu 12 lat od ukazania się artykułu piszącego te słowa Spór o Wierzchowiny... i po ponad roku od zaprezentowania przeze mnie kolejnych dowodów obciażających NSZ w monografii Pod znakiem króla Daniela... Mariusz Bechta i Wojciech J. Muszyński - mimo usilnych starań - nie zdołali podważyć zawartej w nich tezy, że wyłączna odpowiedzialność za mord w Wierzchowinach spoczywa na NSZ.

Na koniec warto zadać pytanie, czemu właściwie miało służyć poświęcenie sporego fragmentu książki sprawie mordu w Wierzchowinach - fragmentu, w którym mamy do czynienia z chaosem faktograficznym i metodologicznym. Dlaczego też Autorzy wyeksponowali zagadnienie Wierzchowin we wstępie do książki, skoro w odpowiedzi na krytyczną recenzję Arkadiusza Karbowiaka Mariusz Bechta (także w imieniu Wojciecha J. Muszyńskiego) asekuracyjnie usprawiedliwiał się, że obaj Autorzy nie rościli sobie pretensji do definitywnego wyjaśnienia „okoliczności likwidowania mieszkańców Wierzchowin”, gdyż nie to było celem ich książki ${ }^{48}$. Do czego zatem rościli sobie pretensje, piszac te kilkadziesiąt stron, które w zasadzie nic nie wnoszą do naukowej dyskusji?

$\mathrm{W}$ związku z powyższym należy stwierdzić, że praca Mariusza Bechty i Wojciecha J. Muszyńskiego w wielu miejscach znacząco odbiega od ogólnie przyjętych standardów monografii naukowej. Obok wspomnianych już rażących błędów rzeczowych czy manipulowania treścią źródeł dotkliwym niedostatkiem

\footnotetext{
${ }^{45}$ G. Motyka, R. Wnuk, Pany i rezuny. Wspótpraca AK-WiNi UPA 1945-1947, Warszawa 1997.

${ }^{46}$ R. Wnuk, Wierzchowiny i Huta, „Polska 1944/45-1989. Studia i Materiały” 1999, t. IV.

${ }^{47}$ K. Komorowski, Polityka i walka. Konspiracja zbrojna ruchu narodowego 1939-1945, Warszawa 2000.

${ }^{48}$ M. Bechta, Wierzchowiny - historia do rewizji..., s. 64.
} 
publikacji jest brak części, która zawierałaby wnioski końcowe. Być może zostały one uznane za zbyteczne, a pracy nie adresowano do szerszego odbiorcy, lecz wyłącznie do czytelnika przekonanego do racji prezentowanych przez obu Autorów, któremu - niezależnie od merytorycznej krytyki zawartych w niej treści - miała się podobać?! Możliwe, że było to też spowodowane pośpiechem Autorów w związku z przypadającymi we wrześniu 2017 r. obchodami 75. rocznicy powstania NSZ. Uroczystości te miała bowiem uświetnić m.in. promocja sygnalnych egzemplarzy recenzowanej książki. W Przeciwko Pax Sovietica.... znalazły się natomiast fragmenty gloryfikujące NSZ, które zostały napisane pod tezę. W efekcie praca ta (przynajmniej w obszarze, o którym mowa w niniejszym artykule recenzyjnym) stanowi wyraźną przestrogę dla następnych pokoleń historyków, jak nie należy pisać książek naukowych! 